\title{
Efektifitas Antibakteri Krim Ekstrak Etanol Biji Alpukat (persea americana mill.) Terhadap Bakteri Staphylococcus aureus
}

\author{
Elok Afrinda Iskarimah ${ }^{1}$, Urmatul Waznah ${ }^{2 *}$, W Wirasti $^{3}$, Dwi Bagus Pambudi ${ }^{4}$ \\ 1,2,3,4Program Studi Sarjana Farmasi, Fakultas Ilmu Kesehatan, Universitas Muhammadiyah \\ Pekajangan Pekalongan, Indonesia \\ *email: urmatul.farmasi@gmail.com
}

\begin{abstract}
Infectious diseases that often occur are infections caused by the Staphylococus aureus bacteria, these bacteria are found on the skin, respiratory tract and digestive tract. The avocado plant (Persea americana Mill.) is a plant whose seeds contain several chemical compounds that can be used as antibacterial agents. The purpose of this study was to determine the antibacterial effectiveness of the avocado seed extract cream (Persea americana Mill.) Against the growth of Staphylococus aureus. Test the inhibition of bacteria using the well method. The extraction method uses the meseration method with $96 \%$ ethanol as solvent. The research results were analyzed using the One-Way ANOVA test. Avocado seed extract (Persea americana Mill.) can be formulated into cream preparations that meet several physical tests of the preparation which include organoleptic test, homogenity test, $\mathrm{pH}$ test, viscosity test, adhesion test and spreadability test. The formulation of avocado seed extract cream (Persea americana Mill.) in this study was able to inhibit the growth of Staphylococcus aureus bacteria with the largest zone of inhibition found at a concentration of $10 \%$ is $19.1 \mathrm{~mm}$. At a concentration of $6 \%$ is $15.1 \mathrm{~mm}$, at a concentration of $8 \%$ is $18.2 \mathrm{~mm}$. With the results of one-way ANOVA statistical tests obtained sig 0,00<0,05 which means that the diameter of the inhibition between formulas was significant.
\end{abstract}

Keywords: Antibacterial, avocado seed extract, cream, Staphylococcus aureus.

\begin{abstract}
Abstrak
Penyakit infeksi yang sering terjadi adalah infeksi yang disebabkan oleh bakteri Staphylococus aureus, bakteri ini terdapat pada kulit, saluran pernafasan, dan saluran pencernaan. Tumbuhan alpukat (Persea americana Mill.) merupakan salah satu tumbuhan yang bagian bijinya memiliki beberapa senyawa kimia yang dapat digunakan sebagai antibakteri. Tujuan dari penelitian ini yaitu untuk mengetahui efektivitas antibakteri dari sediaan krim ekstrak biji alpukat (Persea americana Mill.) terhadap pertumbuhan bakteri Staphylococus aureus. Uji daya hambat bakteri menggunakan metode sumuran. Metode ekstraksi meggunakan metode meserasi dengan pelarut etanol $96 \%$. Hasil penelitian dianalisis dengan menggunakan uji One-Way ANOVA. Ekstrak biji alpukat (Persea americana Mill.) dapat diformulasikan ke dalam sediaan krim yang memenuhi beberapa uji fisik sediaan meliputi uji organoleptis, uji homogenitas, uji pH, uji viskositas, uji daya lekat dan uji daya sebar. Formulasi sediaan krim ekstrak biji alpukat (Persea americana Mill.) pada penelitian ini mampu menghambat pertumbuhan bakteri Staphylococcus aureus dengan zona hambat terbesar terdapat pada konsentrasi $10 \%$ sebesar $19,1 \mathrm{~mm}$. Pada konstrasi $6 \%$ sebesar 15,1 $\mathrm{mm}$, pada konsentrasi $8 \%$ sebesar $18,2 \mathrm{~mm}$. Dengan hasil uji statistik one-way ANOVA diperoleh sig $0,00<0,05$ yang berarti diameter hambat antar formula terdapat perbedaan yang signifikan.
\end{abstract}

Kata kunci: Antibakteri, ekstrak biji alpukat, krim, Staphylococcus aureus. 


\section{Prosiding Seminar Nasional Kesehatan Lembaga Penelitian dan Pengabdian Masyarakat Universitas Muhammadiyah Pekajangan Pekalongan

\section{Pendahuluan}

Di Indonesia alpukat banyak tumbuh liar di hutan-hutan, banyak juga yang ditanam di kebun dan pekarangan rumah. Alpukat merupakan salah satu komoditas buah yang digemari oleh semua lapisan masyarakat. Bagian tanaman alpukat yang banyak dimanfaatkan adalah buahnya sebagai makanan seperti jus maupun campuran es. Selain itu daging buah pada alpukat banyak digunakan dalam bahan masakan bagi masyarakat Eropa. Manfaat lain dari daging buah alpukat adalah sebagai bahan dasar kosmetik. Pada saat ini, alpukat memiliki potensi untuk dibudidayakan secara komersial $[1]$.

Alpukat dimanfaatkan oleh masyarakat hanya buahnya saja, sedangkan biji alpukat masih kurang dimanfaatkan. Biji alpukat melalui penelitian ilmiah terbukti memiliki efek terapi, termasuk antibakteri, antioksidan, antiinflamasi, antijamur dan analgesic [2].

Dalam biji alpukat mengandung flavonoid yang merupakan senyawa antibakteri. Senyawa flavonoid dapat digunakan sebagai antibakteri, antiinflamasi, antibiotic dan obat-obat lainnya. Selain itu senyawa terpenoid, saponin, alkaloid, tannin, fenol, juga termasuk dalam senyawa antibakteri [3].

Staphylococcus aureus merupakan bakteri gram positif yang selalu ditemukan sebagai kuman flora normal pada kulit dan selaput lendir pada manusia. Dalam kondisi tertentu dapat menjadi penyebab infeksi baik pada manusia maupun pada hewan. Setiap jaringan tubuh dapat diinfeksi olehnya dan menyebabkan timbulnya penyakit dengan tanda- tanda yang khas, yaitu peradangan, nekrosis, dan pembentukan abses. Infeksinya dapat berupa furunkel, yang ringan pada kulit sampai berupa suatu piema yang fatal [4].

Berdasarkan latar belakang diatas penulis mengambil judul penelitian "Efektivitas Antibakteri Krim Ekstrak Etanol Biji Alpukat (Persea americana Mill.) Terhadap Bakteri Staphylococcus aureus".

\section{Metode Penelitian \\ Waktu dan Tempat Penelitian}

Penelitian dillakukan pada bulan Mei - Juli 2021 di Laboratorium Mikrobiologi, Laboratorium Fitokimia Prodi Sarjana Farmasi Fakultas Ilmu Kesehatan, Universitas Muhammadiyah Pekajangan Pekalongan.

\section{Alat dan Bahan}

Peralatan yang digunakan dalam penelitian ini antara lain : peralatan gelas/ glassware (Pyrex), autoklaf (Shenan), ayakan mesh 40, batang pengaduk, blender (Isolab), timbangan analitik (Ohaus), vacum rotary evaporator (Heydolph), oven (Memert), cawan petri, botol maserasi, cawan porselen, corong, eksikator, jangka sorong, jarum ose, kapas dan kasa steril, kertas saring, LAF/Laminar air flow (Qoalca), pembakar bunsen, pinset, spatula, waterbath (lokal).

Sampel biji alpukat (Perseae Americana Mill.), etanol 96\%, kertas saring, alumunium foil, aquadest steril, $\mathrm{FeCl}_{3}, \mathrm{NaOH}$, kontrol positif (antibiotik kloramfenikol), setil alcohol, asam stearate, TEA, gliserin, metil paraben, propil paraben, pereaksi 


\section{Prosiding Seminar Nasional Kesehatan 2021 Lembaga Penelitian dan Pengabdian Masyarakat Universitas Muhammadiyah Pekajangan Pekalongan}

dragendorff, pereaksi Mayer, Nutrient Agar (NA), $\mathrm{H}_{2} \mathrm{SO}_{4}, \mathrm{HCl}$ pekat, kloroform, spiritus, serbuk Mg, larutan $\mathrm{NaCl}, 0,5 \mathrm{McFerland}$, bakteri gram positif Staphyloccus aureus.

\section{Prosedur Kerja \\ Determinasi Tanaman}

Biji alpukat (Persea americana Mill.) dalam penelitian yang diperoleh dari Buaran, Kota Pekalongan, Jawa Tengah dilakukan determinasi untuk spesies tanaman yang digunakan adalah Persea americana Mill. Determinasi dilakukan di Laboratorium Biologi Fakultas SAINS dan Teknologi Terapan Universitas Ahmad Dahlan.

\section{Penyiapan Simplisia}

Biji alpukat yang digunakan pada penelitian ini adalah biji alpukat yang masih segar yang diambil dari limbah pedagang jus buah di daerah Buaran, Kota Pekalongan pada bulan Mei 2021. Biji alpukat dilakukan sortasi basah dan dicuci menggunakan air mengalir dengan menyikat kotoran yang menempel. Pengupasan kulit ari biji alpukat yang selanjutnya biji alpukat di potong kecil. Pengeringan dilakukan dengan menjemur sampel dibawah sinar matahari tetapi ditutup menggunakan kain hitam. Penyerbukan dilakukan menggunakan blender. Pengayakan menggunakan ayakan nomor mesh 40.

\section{Pembuatan Ekstrak}

Serbuk biji alpukat (Persea americana Mill.) dimaserasi menggunakan etanol $96 \%$ (1:5) selama 5 hari. Pengadukan dilakukan setiap hari selama 1 jam. Larutan disaring dengan memisahkan filtrat dan residu. Penyaringan dilakukan menggunakan kain flanel pada hari ke-5. Residu digunakan untuk remaserasi dengan $1000 \mathrm{ml}$ etanol $96 \%$ selama 2 hari. Larutan remaserasi disaring dengan memisahkan filtrat dan residu. Filtrat maserasi dan filtrat remaserasi digabungkan kemudian diuapkan menggunakan rotary evaporator pada suhu $40^{\circ} \mathrm{C}$ hingga mendapatkan ekstrak kental kulit jeruk nipis.

\section{Pembuatan Krim}

Semua bahan ditimbang, panaskan lumpang Fase minyak (setil alcohol, asam stearat) dilebur diatas penangas air dalam suhu $70-80^{\circ} \mathrm{C}$ sampai melebur. Fase air (TEA, gliserin, metil paraben, propil paraben) panaskan aquadest pada suhu $70-80^{\circ} \mathrm{C}$ untuk melarutkan metil paraben dan propil paraben. Setelah fase minyak mencair, masukkan kedalam lumpang panas, gerus perlahan, kemudian fase air sedikit demi sedikit gerus sampai rata. Tambahkan ekstrak etanol biji alpukat sesuai dengan konsentrasi, kemudian gerus hingga homogen. Setelah homogen masukkan sediaan pada wadah dan simpan pada suhu kamar.

\begin{tabular}{|c|c|c|c|c|c|}
\hline \multirow[b]{2}{*}{ Bahan } & \multicolumn{4}{|c|}{ Konsentrasi } & \multirow[b]{2}{*}{ Fungsi } \\
\hline & $\begin{array}{l}\text { Kontrol } \\
\text { negatif }\end{array}$ & I & II & III & \\
\hline $\begin{array}{l}\text { Ekstrak biji } \\
\text { alpukat }\end{array}$ & 0 & $6 \%$ & $8 \%$ & $10 \%$ & Zat aktif \\
\hline $\begin{array}{l}\text { Setil alcohol } \\
\text { Asam stearate } \\
\text { Gliserin }\end{array}$ & $\begin{array}{c}1 \mathrm{~g} \\
5 \mathrm{~g} \\
10 \mathrm{~g}\end{array}$ & $\begin{array}{l}1 \mathrm{~g} \\
5 \mathrm{~g} \\
10 \mathrm{~g}\end{array}$ & $\begin{array}{c}1 \mathrm{~g} \\
5 \mathrm{~g} \\
10 \mathrm{~g}\end{array}$ & $\begin{array}{c}1 \mathrm{~g} \\
5 \mathrm{~g} \\
10 \mathrm{~g}\end{array}$ & $\begin{array}{c}\text { Pengemuls } \\
\text { Pengemuls } \\
\text { Emolien }\end{array}$ \\
\hline TEA & $1 \mathrm{~g}$ & $1 \mathrm{~g}$ & $1 \mathrm{~g}$ & $1 \mathrm{~g}$ & $\begin{array}{l}\text { Alkalizing } \\
\text { agent }\end{array}$ \\
\hline $\begin{array}{l}\text { Propil paraben } \\
\text { Metil paraben } \\
\text { Aquadest ad }\end{array}$ & $\begin{array}{c}0,05 \mathrm{~g} \\
0,1 \mathrm{~g} \\
100 \mathrm{~mL}\end{array}$ & $\begin{array}{c}0,05 \mathrm{~g} \\
0,1 \mathrm{~g} \\
100 \mathrm{~mL}\end{array}$ & $\begin{array}{c}0,05 \mathrm{~g} \\
0,1 \mathrm{~g} \\
100 \mathrm{~mL}\end{array}$ & $\begin{array}{c}0,05 \mathrm{~g} \\
0,1 \mathrm{~g} \\
100 \mathrm{~mL}\end{array}$ & $\begin{array}{c}\text { Pengawet } \\
\text { Pengawet } \\
\text { Pelarut }\end{array}$ \\
\hline
\end{tabular}




\section{Prosiding Seminar Nasional Kesehatan 2021 Lembaga Penelitian dan Pengabdian Masyarakat Universitas Muhammadiyah Pekajangan Pekalongan}

\section{Uji Organoleptis}

Sediaan krim dilakukan pengamatan organoleptis seperti warna bentuk dan bau sediaan [5].

\section{Uji pH}

$\mathrm{pH}$ universal dicelupkan kedalam sediaan krim. Kemudian dilihat perubahan skala pada $\mathrm{pH}$ yang merupakan nilai sediaan [6].

\section{Uji Viskositas}

Penentuan viskositas dilakukan dengan menggunakan viscometer digital. Sediaan krim disiapkan. Kemudian memilih nomor spindel yang akan digunakan, yaitu spindel 4. Power alat ditekan dan alat akan mengkalibrasi terlebih dahulu. Setelah itu, memiliki rpm yang digunakan yaitu $60 \mathrm{rpm}$ lalu tekan enter. Pembacaan hasil viskositas dalam Cp [6].

\section{Uji Daya Sebar}

Sebanyak 0,5 gram krim diletakkan ditengah-tengah kaca alroji, kemudian ditutup kaca lain dan dibiarkan 1 menit. Krim yang menyebar diukur diameternya dengan mengambil panjang rata-rata diameter dari beberapa sisi. Kemudian diatasnya ditambahkan beban 50 gram, dibiarkan 1 menit dan diukur diameter sebarnya. Diteruskan penambahan beban tiap kali sebesar 50 gram hingga 250 gram, setelah 1 menit diukur hingga diperoleh diameter yang cukup untuk melihat pengaruh beban terhadap perubahan diameter sebar krim [7].

\section{Uji Daya Lekat}

Sebanyak 0,1 gram krim diletakkan diantara dua obyek glass yang telah ditentukan luasnya $(2 \times 2,5 \mathrm{~cm})$. Diatasnya ditekan dengan beban $1 \mathrm{~kg}$ selama 5 menit. Kemudian obyek glass dipasang pada alat tes, beban dilepaskan dan dicatat waktu hingga kedua obyek glass tersebut terlepas [7].

\section{Uji Antibakteri}

Pada penelitian ini menggunakan 5 kelompok uji yaitu sediaan krim dengan variasi konsentrasi estrak 6\%, $8 \%$ dan 10\%, sediaan krim tanpa ekstrak etanol biji alpukat, serta kontrol positif berupa krim antibiotic kloramfenikol. Metode yang digunakan yaitu metode sumuran. Nutrient Agar (NA) disuspensikan dalam aquades, kemudian dipanaskan hingga mendidih. Dilakukan pengadukan dengan menggunakan magnetic stirrer untuk memastikan media telah tersuspensi secara sempurna. Media yang sudah tersuspensi sempurna, disterilkan dengan autoklaf pada suhu $121^{\circ} \mathrm{C}$ selama 15 menit. Disiapkan media NA, dicelupkan swab steril kedalam suspensi bakteri kemudian digores-goreskan hingga merata pada permukaan media, dibiarkan selama 10 menit supaya suspensi bakteri meresap dalam media agar. Dibuat sumuran dengan menggunakan ependrop steril, yang ditekan pada permukaan media. Dimasukkan krim ekstrak biji alpukat (Perseae Americana Mill.) pada masing-masing sumuran dengan konsentrasi $6 \%$, $8 \%$, dan $10 \%$, kontrol negatif atau basis krim tanpa ekstrak dan kontrol positif kloramfenikol. Diinkubasi pada suhu $37^{\circ} \mathrm{C}$ selama 24 jam. 


\section{Prosiding Seminar Nasional Kesehatan Lembaga Penelitian dan Pengabdian Masyarakat Universitas Muhammadiyah Pekajangan Pekalongan}

\section{Analisis Data}

Analisis data dalam penelitian ini dilakukan dengan menggunakan teknik analisis statistik yang berupa ANOVA one way (analisis varian satu arah). Uji ini dilanjut dengan uji data Diameter Zona Hambat dianalisis secara deskriptif dengan metode analisis statistik yang menggunakan software statistik SPSS.

\section{Hasil dan Pembahasan}

\section{Hasil Penelitian}

Tabel 3.1 Hasil Rendemen Ekstrak Biji Alpukat (Persea americana Mill.)

\begin{tabular}{cccc}
\hline $\begin{array}{c}\text { Berat Serbuk } \\
\text { Simplisia (gram) }\end{array}$ & Berat Ekstrak (gram) & $\begin{array}{c}\text { Rendemen Ekstrak } \\
(\%)(\mathrm{b} / \mathrm{b})\end{array}$ & Kadar Air (\%) \\
\hline 500 & 43,39 & 8,68 & 0,25 \\
\hline
\end{tabular}

Tabel 3.1 Menunjukkan berat serbuk simplisia biji alpukat (Persea americana Mill.) $500 \mathrm{gr}$, berat ekstrak biji alpukat (Persea americana Mill.) 43,39 gr, dan rendemen ekstrak biji alpukat (Persea americana Mill.) 86,8 \%.

Tabel 3.2 Organoleptis Krim Ekstrak Etanol Biji Alpukat (Persea americana Mill.)

\begin{tabular}{ccccc}
\hline \multirow{2}{*}{ Pemeriksaan } & \multicolumn{4}{c}{ Formula } \\
\cline { 2 - 5 } & F0 & F1 & F2 & F3 \\
\hline Warna & Putih & Coklat Muda & Coklat & Coklat tua \\
Bau & Khas & Khas biji alpukat & Khas biji alpukat & Khas biji alpukat \\
Bentuk & Semi padat & Semi padat & Semi padat & Semi padat \\
\hline
\end{tabular}

Tabel 3.2 Menunjukkan pemeriksaan warna, bau dan bentuk pada F0 (basis krim), F1 (ekstrak konsentrasi 6\%), F2 (ekstrak konsentrasi 8\%) dan F3 (ekstrak konstrasi $(10 \%)$.

Tabel 3.3 Homogenitas

\begin{tabular}{cc}
\hline Formula & Pemeriksaan \\
\hline F0 & Homogen \\
F1 & Homogen \\
F2 & Homogen \\
F3 & Homogen \\
\hline
\end{tabular}

Tabel 3.4 pH

\begin{tabular}{cc}
\hline Formula & Pemeriksaan \\
\hline F0 & 6 \\
F1 & 5 \\
F2 & 5 \\
F3 & 6 \\
\hline
\end{tabular}




\section{Prosiding Seminar Nasional Kesehatan Lembaga Penelitian dan Pengabdian Masyarakat Universitas Muhammadiyah Pekajangan Pekalongan

Tabel 3.5 Viskositas

\begin{tabular}{cc}
\hline Formula & Pemeriksaan \\
\hline F0 & 3016 \\
F1 & 3016 \\
F2 & 3018 \\
F3 & 3025 \\
\hline
\end{tabular}

Tabel 3.6 Daya Sebar

\begin{tabular}{cccccc}
\hline \multirow{2}{*}{ Formula } & \multicolumn{5}{c}{ Beban (gr) } \\
\cline { 2 - 6 } & Kaca & 50 & 100 & 150 & 200 \\
\hline F0 & 4,7 & 5,3 & 5,7 & 5,9 & 6,3 \\
F1 & 4,5 & 4,9 & 5,3 & 5,7 & 5,9 \\
F2 & 4,4 & 4,9 & 5,2 & 5,5 & 5,9 \\
F3 & 4,4 & 4,7 & 4,9 & 5,1 & 5,6 \\
\hline
\end{tabular}

Tabel 3.7 Daya Lekat

\begin{tabular}{cc}
\hline Formula & Pemeriksaan \\
\hline F0 & 4,02 \\
F1 & 4,23 \\
F2 & 4,42 \\
F3 & 4,60 \\
\hline
\end{tabular}

Tabel. 3.8 Daya Hambat Ekstrak Etanol Biji Alpukat (Persea americana Mill.)

\begin{tabular}{cc}
\hline Formula & Daya Hambat \\
\hline Kontrol positif & $32,6 \pm 0,17$ \\
F0 & $12,0 \pm 0,59$ \\
F1 & $15,1 \pm 015$ \\
F2 & $18,2 \pm 0,35$ \\
F3 & $19,1 \pm 0,72$ \\
\hline
\end{tabular}

Hasil daya hambat antibakteri krim ekstrak etanol biji alpukat dapat dilihat pada gambar 1.

Daya Hambat

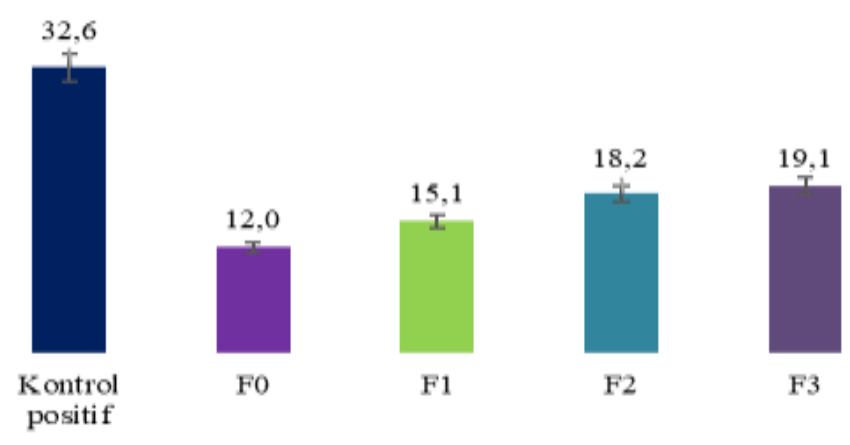

Gambar 3.9 Diagram Daya Hambat 


\section{Prosiding Seminar Nasional Kesehatan 2021 Lembaga Penelitian dan Pengabdian Masyarakat Universitas Muhammadiyah Pekajangan Pekalongan}

ANOVA

Daya Hambat

\begin{tabular}{|c|c|c|c|c|c|c|}
\hline & $\begin{array}{l}\text { Sum of } \\
\text { Squares }\end{array}$ & Df & & Mean Square & $\mathrm{F}$ & Sig. \\
\hline Between & 74933.333 & & 4 & 18733.333 & 906.452 & .000 \\
\hline \multicolumn{7}{|l|}{ Groups } \\
\hline Within Groups & 206.667 & & 10 & 20.667 & & \\
\hline Total & 75140.000 & & 14 & & & \\
\hline
\end{tabular}

\section{Pembahasan}

\section{Determinasi}

Determinasi merupakan suatu proses yang spesifik dalam penentuan nama atau spesies pada tumbuhan tertentu. Tujuan dilakukannya determinasi yaitu untuk memastikan keaslian tanaman sampel yang digunakan untuk penelitian. Determinasi sampel dilakukan di Laboratorium Biologi Fakultas SAINS dan Teknologi Terapan Universitas Ahmad Dahlan pada bulan Juni 2021.

$1 b-2 b-3 b-4 b-6 b-7 b-9 b-10 b-11 b-12 b-13 b-14 a-15 a-109 b 0119 b$ $-120 a-121 b-124 b-125 a-126 b-127 b-135 b-136 b-139 b-140 b-142 b-$ 143b Lauraceae

1a - 2a Persea

Persea americana Mill.

Hasil determinasi sampel menyatakan bahwa tanaman sampel adalah alpukat (Persea americana Mill.). Tanaman sampel diambil di Kecamatan Buaran, Kota Pekalongan, Provinsi Jawa Tengah.

\section{Ekstraksi}

Hasil ekstraksi kulit jeruk nipis didapatkan ekstrak kental dengan nilai rendemen $8,68 \%$. Rendemen ekstrak adalah senyawa zat aktif yang bisa diambil dari simplisianya yang merupakan perbandingan antara total ekstrak yang didapatkan dengan bobot serbuk simplisia yang digunakan untuk ekstraksi. Rendemen ekstrak menyatakan bahwa adanya senyawa kimia yang terkandung dalam serbuk simplisia biji alpukat terekstraksi oleh pelarut. Semakin banyak nilai rendemen ekstrak yang dihasilkan maka semakin banyak pula senyawa kimia yang dihasilkan.

\section{Uji Oragonoleptis}

Pengamatan organoleptis bertujuan untuk mengetahui ada tidaknya perubahan secara organoleptis selama penyimpanan. Hasil uji organoleptis F0 dari mempunyai warna putih, beraroma khas krim dan berbentuk semi padat. Untuk F1, F2 dan F3 dari mempunyai karakteristik warna coklat muda hingga coklat tua, dengan aroma khas biji alpukat dan bentuk semi padat.

\section{Uji Homogenitas}

Diperoleh hasil yang homogen, karena krim tercampur merata dan tidak terdapat butiran-butiran saat dioleskan pada kaca objek. Persyaratan homogenitas krim dimaksudkan agar persamaan warna yang terdistribusi merata, pada proses 


\section{Prosiding Seminar Nasional Kesehatan Lembaga Penelitian dan Pengabdian Masyarakat Universitas Muhammadiyah Pekajangan Pekalongan}

pengamatan tidak mengalami pemisahan antara bahan minyak dan air. Sehingga menunjukan sediaan tersebut memiliki homogenitas yang stabil.

\section{Uji pH}

Pengamatan diatas dihasilkan bahwa pH pada F0 dan F3 semua diperoleh pH sebesar 6 . Untuk F1 dan F2 diperoleh pH sebesar 5 secara berturut-turut. Pengukuran $\mathrm{pH}$ dengan menggunakan universal indikator $\mathrm{pH}$. Pengukuran $\mathrm{pH}$ ini bertujuan untuk mengetahui apakah sediaan krim yang telah dibuat bersifat asam atau basa. Sediaan yang bersifat basa tidak masuk kedalam kriteria rentang $\mathrm{pH}$ pada kulit, dimana $\mathrm{pH}$ kulit untuk topikal yaitu pH 4 -7. Karena jika pH basa akan mengakibatkan kulit terasa licin, cepat kering dan dapat mempengaruhi elastisitas kulit.

\section{Uji Viskositas}

Uji viskositas yang didapatkan F0, F1, F2, dan F3 mengalami peningkatan viskositas. Viskositas meningkat seiring peningkatan konsentrasi ekstrak, sehingga semakin besar konsentrasi ekstrak yang dimasukkan kedalam sediaan maka semakin meningkat pula viskositasnya. Keempat formula krim tersebut memenuhi syarat yaitu antara $500-20000$ cp.s [8].

\section{Uji Daya Sebar}

Tujuan dari uji daya sebar pada sediaan krim yaitu untuk mengetahui kemampuan sediaan krim untuk menyebar pada permukaan kulit. Dari data yang diperoleh daya sebar diatas dapat dilihat penurunan daya sebar krim konsentrasi, penurunan daya sebar ini disebabkan karena peningkatan viskositas sediaan krim. Daya sebar yang baik yaitu sekitar 4-6,5 cm sehingga krim dapat dengan mudah dioleskan pada kulit tanpa penekanan yang kuat dengan jari tangan [8].

\section{Uji Daya Lekat}

Dari data yang diperoleh semakin tinggi konsentrasi ekstrak maka daya lekat yang dihasilkan semakin tinggi. Hal tersebut karena daya lekat sediaan krim berbanding lurus dengan viskositas atau kekentalan sediaan. Sehingga semakin tinggi konsentrasi ekstrak yang ditambahkan maka semakin kental konsistensi sediaan krim yang menyebabkan waktu perlekatan sediaan krim semakin lama. Krim yang baik mampu menjamin waktu kontak yang efektif dengan kulit sehingga tujuan penggunaannya tercapai. Krim dengan daya lekat baik untuk sediaan topical yaitu lebih dari 4 detik [9].

\section{Uji Antibakteri}

Pengujian aktivitas antibakteri dilakukan dalam keadaan steril, sehingga alat, bahan dan ruangan harus disterilkan terlebih dahulu agar terhindar dari mikroba. Hasil rata-rata daya hambat krim dengan konsentrasi ekstrak $6 \%$ sebesar $15,1 \mathrm{~mm}$, konsentrasi ekstrak $8 \%$ sebesar 18,2 mm, konsentrasi $10 \%$ sebesar 19,1 mm, dari ketiga data tersebut menunjukkan bahwa daya hambat yang dihasilkan termasuk kuat. Untuk hasil aktivitas antibakteri pada kontrol negatif yang berisi basis krim sebesar 12 $\mathrm{mm}$ yang termasuk daya hambat kuat, hal ini adanya pengaruh kandungan pengawet dalam sediaan krim yang berfungsi dapat menghambat bakteri Staphylococcus Aureus. Kontrol positif krim kloramfenikol memiliki daya hambat sebesar 32,6mm yang 


\section{Prosiding Seminar Nasional Kesehatan Lembaga Penelitian dan Pengabdian Masyarakat Universitas Muhammadiyah Pekajangan Pekalongan}

termasuk daya hambat sangat kuat. Dari hasil pengamatan diatas menunjukan bahwa aktivitas antibakteri terbesar terdapat pada krim dengan konsentrasi $10 \%$. Adanya kandungan senyawa aktif berupa fenol, flavonoid, terpenoid dan tanin. Menurut penelitian dari Rahmadani (2015) senyawa tersebut dapat menghambat bakteri Staphylococcus aureus. Semakin besar kadar konsentrasi ekstrak kandungan senyawa metabolit sekunder yang terdapat didalamnya semakin tinggi, sehingga daya hambat terhadap bakteri Staphylococcus aureus lebih besar. Masing-masing senyawa memiliki mekanisme dalam menghambat bakteri, diantaranya yaitu senyawa fenolik secara memiliki sifat bakterisidal, antiseptik, dan antihelmintik. Sedangkan digunakan kontrol positif krim kloramfenikol untuk membandingkan zona hambat sebagai gambaran terbunuhnya bakteri.

\section{Kesimpulan}

Formulasi sediaan krim ekstrak biji alpukat (Persea americana Mill.) pada penelitian ini mampu menghambat pertumbuhan bakteri Staphylococcus aureus dengan zona hambat terbesar terdapat pada konsentrasi $10 \%$ sebesar 19,1 mm. Pada konstrasi $6 \%$ sebesar $15,1 \mathrm{~mm}$, pada konsentrasi $8 \%$ sebesar $18,2 \mathrm{~mm}$. Dengan hasil uji statistik one-way ANOVA diperoleh sig 0,00<0,05 yang berarti diameter hambat antar formula terdapat perbedaan yang signifikan.

\section{Referensi}

[1] A. Chandra, H. M. Inggrid, and Verawati, "Pengaruh pH dan Jenis Larutan Perendam pada Perolehan dan Karakterisasi Pati dari Biji Alpukat," J. Lemb. Penelit. dan Pengabdi. Kpd. Masy. Univ. Katolik Parahyangan 2013, pp. 30-39, 2013.

[2] D. P. A. Rachman, L. Mulqie, and R. S. E. Endah, "Uji Aktivitas Antibakteri Fraksi Ekstrak Etanol Biji Alpukat ( Persea americana Miller ) terhadap Bakteri Propionibacterium acnes," pp. 388-393, 2016.

[3] A. C. C Egbuonu, "Proximate, Functional, Antinutrient and Antimicrobial Properties of Avocado Pear (Persea americana) Seeds," J. Nutr. Heal. Food Eng., vol. 8, no. 1, pp. 78-82, 2018.

[4] N. Fadhillah Thamrin, "Formulasi Sediaan Krim dari Ekstrak Etanol Kunyit (Curcuma domesticae. Val) dan Uji Efektivitas terhadap Bakteri Staphylococcus aureus [Skripsi]," NASPA J., p. 124, 2012.

[5] Ansel, H. 2008. Pengantar Bentuk Sediaan Farmasi. Universitas Indonesia Press. Jakarta.

[6] Martin A, Swarbick. J. Farmasi Fisik Edisi III. Diterjemahkan oleh Yoshita. Jakarta : UI Press. 2013.

[7] Elcistia, R., \& Zulkarnain, A. K. (2018). Optimasi Formula Sediaan Krim o/w Kombinasi Oksibenzon dan Titanium Dioksida Serta Uji Aktivitas Tabir Suryanya Secara In Vivo. Jurnal Majalah Farmaseutik, Vol. 14 No. 2. Yogyakarta : Universitas Gadjah Mada. 


\section{Prosiding Seminar Nasional Kesehatan Lembaga Penelitian dan Pengabdian Masyarakat 2021 Universitas Muhammadiyah Pekajangan Pekalongan}

[8] Nuralifah., Armadany, F, I., Parawansah., Pratiwi, A. (2018). Uji Aktivitas Antibakteri Sediaan Krim Anti Jerawat Ekstrak Etanol Terpurifikasi Daun Sirih (Piper betle L) dengan Basis Vanishing Cream Terhadap Propionibacterium acne. Jurnal Farmasi, Sains, dan Kesehatan 4 (2): Kendari.

[9] Mawarni, F, N, A. (2018). Formulasi Krim Ekstrak Etanol Daun Salah Syzygium Polyanthum (Wight) Walp.) Dan Uji Aktivitas Antioksidan Dengan Metode DPPH. Skripsi. Universitas Setia Budi Surakarta. 